Research Article

\title{
Genetic diversity and population structure of Vriesea reitzii (Bromeliaceae), a species from the Southern Brazilian Highlands
}

\author{
Luis Eduardo Soares ${ }^{1,2, *}$, Márcia Goetze ${ }^{1 *}$, Camila M. Zanella ${ }^{1,3}$ and Fernanda Bered ${ }^{1}$ \\ ${ }^{1}$ Universidade Federal do Rio Grande do Sul, Instituto de Biociências, Programa de Pós-graduação em \\ Genética e Biologia Molecular, Porto Alegre, RS, Brazil. \\ ${ }^{2}$ Department of Molecular Developmental Biology, Faculty of Science, Radboud Institute for Molecular Life \\ Sciences, Radboud University, Nijmegen, The Netherlands. \\ ${ }^{3}$ The John Bingham Laboratory, National Institute of Agricultural Botany (NIAB), Cambridge, UK
}

\begin{abstract}
The Southern Brazilian Highlands are composed by a mosaic of Mixed Ombrophilous Forest (MOF) and grassland formations, an interesting landscape for the study of population structure. We analyzed the genetic diversity within and among populations of the MOF-endemic bromeliad Vriesea reitzii by genotyping seven nuclear microsatellite loci in 187 individuals from six populations. We characterized levels of genetic diversity and assessed the genetic structure among populations. Vriesea reitzii populations showed high levels of genetic variation (number of alleles 28 - 43, allelic richness $3.589-5.531)$ and moderate levels of genetic differentiation $\left(F_{\mathrm{ST}}=0.123, R_{\mathrm{ST}}=0.096\right)$. The high levels of genetic diversity may be explained by species life-history traits, such as habit and mating system. The moderate structure may be a product of the combination of ancient and contemporary gene flow, resulting from the expansion of the forest in the Holocene, and/or due to facilitated dispersal mediated by the MOF's mosaic landscape. The genetic results indicated no imminent threat to this bromeliad. However, the species is highly associated with the MOF, putting landscape conservation at the center of conservation efforts for the species' maintenance.
\end{abstract}

Keywords: Mixed Ombrophilous Forest, bromeliad, Araucaria forest, gene flow, conservation.

Received: March 06, 2017; Accepted: July 22, 2017.

\section{Introduction}

The Brazilian Atlantic rainforest (BAF) represents the second largest tropical moist forest in the world and is recognized for its high levels of biodiversity and endemism (Ledru et al., 2016). The BAF is an ecogeographically subdivided biome. By its broadest definition, it includes several types of vegetation, including semi-deciduous and mixed forests, in addition to the ombrophilous forest of the coast (Oliveira Filho and Fontes, 2000; Goetze et al., 2015). At the southernmost limit of the BAF sensu lato lies the Mixed Ombrophilous Forest (MOF), or Araucaria Forest, which extends up to $700 \mathrm{~km}$ inland (Oliveira Filho and Fontes, 2000). It is disjunctly distributed across the southern plateau of Southeastern Brazil, between $24^{\circ}$ and $30^{\circ} \mathrm{S}$, at altitudes between 500 and $1400 \mathrm{~m}$ above sea level (Behling and Pillar, 2007).

Send correspondence to Fernanda Bered. Universidade Federal do Rio Grande do Sul, Instituto de Biociências, Programa de Pós-graduação em Genética e Biologia Molecular, Avenida Bento Gonçalves 9500, P.O. Box 15053, 91501-970, Porto Alegre, RS, Brasil. E-mail: fernanda.bered@ufrgs.br.

*These authors contributed equally to this work
The Araucaria Plateau is a geomorphological unit that occupies approximately three-quarters of the southern area of South Brazil, between the Iguaçú and Uruguay Rivers (Behling and Pillar, 2007; Calegari et al., 2017). Its vegetation is characterized by a mosaic of MOF and grassland formations. In the grassland areas it is common to find Araucaria angustifolia in an irregular distribution, together with "capões" (clumps of trees) and gallery forest, whose floristic composition is similar to that of the MOF (Calegari et al., 2017). The origin of this mosaic, which is characteristic of the Southern Brazilian highlands, has been widely debated. According to Behling et al. (2005), several palaeoecological studies carried out in this region have proven that extensive areas of grassland vegetation existed on the highlands throughout the glacial, early and mid-Holocene periods, with forests restricted to deep valley refuges. Mounting evidence suggests that around 3000 years ago, during the Holocene, the MOF expanded from the gallery forests along the rivers as a result of increasing temperatures and humidity (Behling et al., 2004).

Starting around the First World War, fueled by difficulties in commercializing pine wood from Latvia, Europeans began to explore the Brazilian pine Araucaria angus- 
tifolia. As a consequence, the MOF has suffered a further drastic reduction in its geographic distribution, giving way to the current patchwork of pasture, monoculture stands of Pinus and Eucalyptus, and open fields interspersed with Araucaria fragments (Fonseca et al., 2009; Boelter et al., 2011). In spite of these known - ancient and more recent factors, the origin of the formation of this mosaic remains unknown, and the effect of human impact on the overall biodiversity of the region throughout time is ill understood.

In fragmented or mosaic landscapes, genetic exchange among plants tends to be restricted, and high genetic differentiation among spatially isolated populations might be expected as a result of random genetic drift, restricted gene flow or selection (Frei et al., 2012; Devitt et al., 2013; Maurice et al., 2016). Studies addressing plant population structure in the MOF are restricted almost exclusively to Araucaria angustifolia (e.g., Bittencourt and Sebbenn, 2007; Danner et al., 2013; Medina-Macedo et al., 2015). In order to develop a better understanding of the dynamics of this particular mosaic of forest and grassland in the Southern Brazilian Highlands, the contribution of data from other species is crucial.

The family Bromeliaceae is widespread across the Neotropical region and occupies most distinct environments in the American continent (Brown and Gilmartin, 1989; Smith and Till, 1999; Benzing, 2000; Givnish et al., 2014). Within the BAF, the bromeliads are one of the species richest and most diverse families, therefore representing an important component of this biome (Martinelli et al., 2008). Vriesea is the third largest bromeliad genus. It comprises approximately 290 species, $94.8 \%$ of which are endemic to Brazil (Costa et al., 2014; Barfuss et al., 2016). The main center of diversity of the genus lies in the BAF (Costa et al., 2014), and most population genetic studies on Vriesea focus on species from the coastal regions, or BAF sensu stricto (Alves et al., 2004; Palma-Silva et al., 2009; Zanella et al., 2012, 2016). Additional studies have investigated the genetic patterns of bromeliads restricted to higher altitudes of Andean landscape, such as Puya raimondii (Sgorbati et al., 2004), as well as tropical inselbergs and outcrops (Barbará et al., 2009; Boisselier-Dubayle et al., 2010; Domingues et al., 2011; Ribeiro et al., 2013; Lavor et $a l ., 2014)$. However, little is known about species endemic to the MOF.

Here, we investigate the genetic diversity within and among populations of the MOF-endemic bromeliad Vriesea reitzii Leme \& A.F. Costa, across its entire geographic distribution. Vriesea reitzii is an epiphytic bromeliad that occurs in MOF fragments at altitudes ranging from 750 to 1200 m (Rech-Filho et al., 2005; Alves et al., 2006). Due to its morphological similarity with $V$. philippocoburgii, $V$. reitzii was, for a long time, neglected as a species. However, morphological and ecological characteristics have led to the recognition of two distinct taxonomic units (Leme and Costa, 1991). Due to this very recent description of $V$. reitzii as a separate species there is an almost complete lack of data on its breeding system, life history and demographics. However, based on the great resemblance between $V$. reitzii and $V$. phillipocoburgii, it is reasonable to hypothesize that the two species share the same or very similar characteristics. Vriesea phillipocoburgii is an epiphyte bromeliad pollinated by hummingbirds, whose seeds are dispersed by the wind (Machado and Semir, 2006; Fischer EA, 1994, Master's thesis, Universidade Estadual de Campinas). In the only previously published report on the demography and life history of $V$. reitzii, Favretto and Geuster (2012) found that the species bloomed during the spring in the municipality of Joaçaba, Santa Catarina. According to the authors, the species reaches high population densities in places with a good exposure to light.

In addition to the potential conservation implications of our work, this study is motivated by a desire to understand the genetic structure of populations from an extremely fragmented mosaic landscape, the Southern Brazilian Highlands, using $V$. reitzii as model. We hypothesized that the populations of $V$. reitzii would show a high level of genetic structure, similar to other bromeliad species that have been studied on inselbergs. However, there are no reports of genetic population studies in MOF bromeliads, and their genetic structure remains unknown. The specific aims of the present study were: (i) to assess the intra- and interpopulation genetic diversity of $V$. reitzii using nuclear DNA; (ii) to quantify the degree of genetic differentiation among populations and discuss the results in the light of the particularity of the forest and grassland mosaic covering the Southern Brazilian Highlands; (iii) to provide data as a basis for conservation actions for the species.

\section{Material and Methods}

\section{Sampling and DNA extraction}

We sampled six populations of $V$. reitzii, covering its entire geographical distribution across the Mixed Ombrophilous Forest. In preparation of the sample collection, we consulted herbarium records and contacted national parks and other locations, for which the species was described. In many of these places, the species was not found anymore, demonstrating the influence of human action on the distribution of $V$. reitzii. We believe that we sampled the main localities where $V$. reitzii currently occurs. The minimum distance between populations was approximately $38 \mathrm{~km}$ (CFRS to SFRS), with a maximum of about $360 \mathrm{~km}$ (CSRS to SMPR). Altitudes ranged from $778 \mathrm{~m}$ to $1031 \mathrm{~m}$ above sea level (Table 1 and Figure 1). Fresh leaves from 187 flowering or fruiting individuals (approximately 30 per population) were collected and fast dried in silica gel. Total genomic DNA was extracted using the cetyltrimethylammonium bromide (CTAB) protocol, as described by Doyle and Doyle (1990). DNA quantification was performed on a 
Table 1 - Populations of Vriesea reitzii sampled, with their vouchers and geographical parameters.

\begin{tabular}{|c|c|c|c|c|c|}
\hline Population Code & Sampling site & Voucher & State* & Coordinates & Altitude (m) \\
\hline SMPR & São Mateus do Sul & UPCB36191 & PR & $\mathrm{S} 25^{\circ} 52^{\prime} \mathrm{W} 50^{\circ} 18^{\prime}$ & 778 \\
\hline CASC & Campo Alegre & RB00287263 & $\mathrm{SC}$ & S $26^{\circ} 10^{\prime} \mathrm{W} 49^{\circ} 13^{\prime}$ & 977 \\
\hline PDSC & Papanduva & $-\S$ & $\mathrm{SC}$ & $\mathrm{S} 26^{\circ} 30^{\prime} \mathrm{W} 50^{\circ} 14^{\prime}$ & 790 \\
\hline LGSC & Lages & LUSC5573 & $\mathrm{SC}$ & $\mathrm{S} 27^{\circ} 47^{\prime} \mathrm{W} 50^{\circ} 21^{\prime}$ & 1031 \\
\hline CSRS & Cambará do Sul & HAS30158 & RS & $\mathrm{S} 29^{\circ} 08^{\prime}, \mathrm{W} 50^{\circ} 05^{\prime}$ & 977 \\
\hline SFRS & São Francisco de Paula & HAS66297 & RS & $\mathrm{S} 29^{\circ} 26^{\prime} \mathrm{W} 50^{\circ} 36^{\prime}$ & 927 \\
\hline
\end{tabular}

*Brazilian Federal States: RS, Rio Grande do Sul; SC, Santa Catarina; PR, Paraná.

$\S$ Unable to retrieve voucher from this population.

UPBC, Herbarium Departamento de Botânica, Universidade Federal do Paraná; RB, Herbário do Jardim Botânico do Rio de Janeiro; LUSC, Herbarium Lages da Universidade Federal de Santa Catarina; HAS, Herbário Prof. Dr. Alarich Rudolf Holger Schultz, Museu de Ciências Naturais da Fundação Zoobotânica do Rio Grande do Sul.

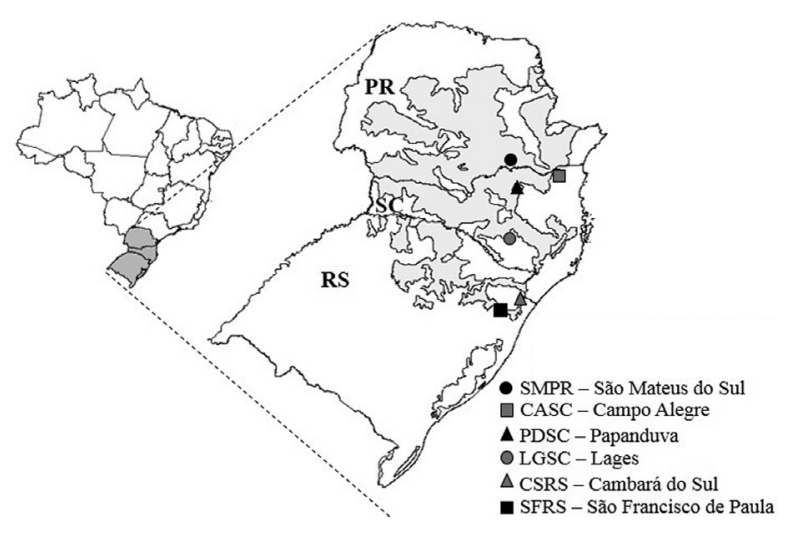

Figure 1 - Brazilian map highlighting the southern region with Mixed Ombrophilous Forest in gray. The six Vriesea reitzii populations sampled for this study are marked according to legend.

$1 \%$ agarose gel stained with GelRed (Biotium, Hayward, CA, USA), in comparison with $\lambda$ phage DNA.

\section{Molecular markers and genotyping assays}

All samples were genotyped for seven nuclear microsatellite loci described for different bromeliads species: e6B and e19, from Tillandsia fasciculata (Boneh et al., 2003); PaA10, from Pitcairnia albiflos (Paggi et al., 2008), and $\mathrm{VgB10}, \mathrm{VgC01}$ and $\mathrm{VgF} 02$, from Vriesea gigantea (Palma-Silva et al., 2007). We also genotyped VgF05, an unpublished locus isolated from $V$. gigantea (primers $\mathrm{F}$ : TGGGATCATTTCCTTGTTCC,

$\mathrm{R}$ : CATTCTTGTTTCGCCCAAAT). Amplification reactions were carried out in a TC-412 Thermal Cycler (Techne, Burlington, New Jersey, USA), as described by PalmaSilva et al. (2007). The microsatellite alleles were resolved on an ABI 3100 DNA Analyzer Sequencer (Applied Biosystems, Foster City, CA, USA) and sized against the GS500 LIZ molecular size standard (Applied Biosystems) using GENEMARKER Demo version 1.97 (SoftGenetics, State College, PA, USA).

\section{Data Analyses}

The genetic diversity of each population was characterized using the number of alleles (A), number of private alleles $\left(\mathrm{A}_{\mathrm{P}}\right)$, allelic richness $\left(R_{S}\right)$, expected $\left(H_{\mathrm{E}}\right)$ and observed $\left(H_{\mathrm{O}}\right)$ heterozygosities, and the inbreeding coefficient ( $F_{\text {IS }}$; Weir and Cockerham, 1984), using the programs FSTAT 2.9.3.2 (Goudet, 1995) and MSA 4.05 (Dieringer and Schlötterer, 2003). To examine departures from the Hardy-Weinberg equilibrium (HWE), exact tests were carried out in GENEPOP 4.0 (Raymond and Rousset, 1995). The data were also tested for genotyping errors resulting from stuttering, short allele dominance, and null alleles using a Monte Carlo simulation of expected allele-size differences implemented in MICRO-CHECKER 2.2.3 (van Oosterhout et al., 2004).

Each population was tested for recent population size reductions (e.g., genetic bottlenecks), using a heterozygosity excess test implemented in the software BOTTLENECK 1.2.02 (Piry et al., 1999). The analysis was carried out using a two-phased mutation model (TPM), with $12 \%$ variance and $95 \%$ stepwise mutations. Statistical significance was assessed in 10,000 replicates using a onetailed Wilcoxon signed-rank test. In addition, the occurrence of a genetic bottleneck was tested by estimating the $M$-ratio, the mean ratio of the number of alleles (k) to the range in allele size (r) using the software ARLEQUIN 3.5.2.2 (Excoffier and Lischer, 2010). This method takes advantage of the size specificity of microsatellite allelic states. Significance for each population was assessed by comparison of $M$-ratios with the critical values ( $M_{\mathrm{c}}$ values) obtained by simulating the distribution of $M$-ratios under specific demographic and mutational conditions using the software CRITICAL_M.EXE (http://swfsc.noaa.gov/ textblock.aspx?Division=FED\&id=3298) according to Goetze et al. (2016). Population genetic differentiation was assessed based on $F_{\mathrm{ST}}$ (Weir and Cockerham, 1984), on the standardized genetic differentiation measure $G$ 'sT (Hedrick, 2005), and on Slatkin's $R_{\mathrm{ST}}$ (Slatkin, 1995), which estimates the contribution of stepwise-like mutations to genetic differentiation. All these parameters were calculated 
in the FSTAT software. Pairwise comparisons of $F_{\mathrm{ST}}$ between populations were carried out using the program ARLEQUIN. The partitioning of genetic diversity within and among populations was examined by Analysis of Molecular Variance (AMOVA; Excoffier et al., 1992) implemented in the software ARLEQUIN. The hypothesis that populations are differentiated because of isolation-by-distance (Wright, 1965) was tested by calculating the correlation between geographic and genetic distance matrices $\left(F_{\mathrm{ST}}\right)$, with a standardized Mantel test (Sokal and Rohlf, 1995) using GENEPOP. We also used a Bayesian assignment approach to investigate the population structure of $V$. reitzii, using STRUCTURE 2.3.4 (Pritchard et al., 2000), aiming to assign individuals to genetic clusters $(K)$ and to estimate admixture proportions $(Q)$ for each individual. The proportion of membership for each cluster was calculated without the consideration of sampling localities. The analyses were carried out under the admixture model assuming independent allele frequencies and using a burn-in period of 250,000, run lengths of $10^{6}$ and 10 iterations per $K$, for $K$ ranging from 1 to 8 , to confirm stabilization of the summary statistics (Pritchard et al., 2000). To determine the most likely number of clusters $(K)$, we used the method proposed by Evanno et al. (2005), which is based on an ad hoc measure of $\Delta K$ that evaluates the second-order rate of change of the likelihood function with respect to $K$. The calculation of $\Delta K$ was done with STRUCTURE HARVESTER version 0.6.94 (Earl and von Holdt, 2012).

The effective number of migrants $\left(N_{\mathrm{e}} m\right)$ between pairs of populations was estimated using a coalescent theory and maximum-likelihood-based approach using MIGRATE 3.0.3 (Beerli and Felsenstein, 1999), as described by Barbará et al. (2007). Computations were carried out under both the infinite allele model (IAM) and the Stepwise Mutation Model (SMM), and mutation rates $(\mu)$ for each locus were estimated from the data.

\section{Results}

Relatively high levels of genetic variation were found in $V$. reitzii populations (Table 2 ). The number of alleles at each locus ranged from 28 to 43, and the allelic richness ranged from 3.589 to 5.531, both in SMPR and CASC, respectively. The observed heterozygosity ranged from 0.411 to 0.499 , with the expected heterozygosity ranging from 0.452 to 0.629 . With the exception of PDSC, all populations had private alleles. Inbreeding coefficients ranged from 0.089 to 0.310 , and with the exception of SMPR, all populations departed significantly from HWE with an excess of homozygotes (Table 2). Micro-Checker analysis detected the presence of null alleles at six loci in different populations (data not shown). No signs of reduction in population size were detected by any of the methods used (Bottleneck analysis and $M$-ratio) for any of the populations investigated.

Moderate levels of genetic differentiation were detected among $V$. reitzii populations $\left(F_{\mathrm{ST}}=0.123, \mathrm{G}_{\mathrm{ST}}=\right.$ 0.120 and $\left.R_{\mathrm{ST}}=0.096\right)$. The pairwise $F_{\mathrm{ST}}$ values also suggest low to moderate structure between pairs of populations, and geographical proximity does not seem to be the main factor determining the $F_{\mathrm{ST}}$ (e.g., CASC and PDSC showed a significant $F_{\mathrm{ST}}=0.100(P<0.001)$ and are $108 \mathrm{~km}$ apart, whereas SMPR and CSRS showed a nonsignificant $F_{\mathrm{ST}}=0.030$ and are $360 \mathrm{~km}$ apart (see Figure 1 and Table 3). Accordingly, the Mantel test revealed that geographical distances were not significantly correlated with genetic differentiation as estimated by $r^{2}=0.0001(P=$ 0.364 ), suggesting the absence of isolation-by-distance.

AMOVA results indicated that the largest percentage of variation $(87.42 \%)$ was attributed to the within populations component and only a small portion of the genetic variance $(12.58 \%)$ was attributed to the between populations component $(P<0.0001)$.

Bayesian analysis confirmed that a model of $K=3$ groups best captured the variation in the data from $V$. reitzii (Figure $\mathrm{S} 1$ ). The admixture proportions $(Q)$ for each individual are shown in Figure 2. The number of migrants per

Table 2 - Characterization of genetic variability in six populations of Vriesea reitzii.

\begin{tabular}{|c|c|c|c|c|c|c|c|c|}
\hline Population & $\mathrm{N}$ & $M$-ratio ${ }^{1}$ & A & $\mathrm{A}_{\mathrm{P}}$ & $R_{\mathrm{S}}$ & $H_{\mathrm{O}}$ & $H_{\mathrm{E}}$ & $F_{\text {IS }}$ \\
\hline SMPR & 31 & 0.732 & 28 & 1 & 3.589 & 0.411 & 0.452 & 0.089 \\
\hline CASC & 31 & 0.732 & 42 & 4 & 5.531 & 0.438 & 0.629 & $0.310^{*}$ \\
\hline PDSC & 30 & 0.729 & 31 & 0 & 3.846 & 0.360 & 0.504 & $0.286^{*}$ \\
\hline LGSC & 32 & 0.733 & 43 & 6 & 5.307 & 0.499 & 0.533 & $0.019^{*}$ \\
\hline CSRS & 32 & 0.733 & 38 & 1 & 4.955 & 0.493 & 0.571 & $0.137^{*}$ \\
\hline SFRS & 31 & 0.732 & 40 & 3 & 5.100 & 0.419 & 0.515 & $0.167 *$ \\
\hline
\end{tabular}

$\mathrm{N}$, number of individuals; $M$-ratio, mean ratio of the number of alleles to the range in allele size; A, number of alleles; $\mathrm{A}_{\mathrm{P}}$, number of private alleles; $R_{\mathrm{S}}$, allelic richness; $H_{\mathrm{O}}$, observed heterozygosity; $H_{\mathrm{E}}$, expected heterozygosity; $F_{\mathrm{IS}}$, inbreeding coefficient.

${ }^{1}$ population is considered to have undergone a bottleneck if its $M$-ratio value falls below the threshold of critical $M$-ratio calculated ( 0.61$)$. No bottlenecks were detected in the six populations.

* Inbreeding coefficient $\left(F_{\text {IS }}\right)$ which departed significantly from Hardy-Weinberg equilibrium $(\mathrm{HWE})$ at the $P<0.001$ level. 
Table 3 - Pairwise genetic divergence $\left(F_{\mathrm{ST}}\right)$ below the diagonal and number of effective migrants $\left(N_{\mathrm{e}} \mathrm{m}\right)$ per generation above the diagonal, for Vriesea reitzii populations based on seven microsatellite loci.

\begin{tabular}{lcccccc}
\hline & SMRS & CASC & PDSC & LGSC & CSRS & SFRS \\
\hline SMRS & & 0.377 & 0.145 & 1.161 & 0.748 & 0.933 \\
CASC & $\mathbf{0 . 0 9 7}$ & & 1.605 & 1.103 & 2.541 & 2.671 \\
PDSC & 0.044 & $\mathbf{0 . 1 0 0}$ & & 0.663 & 0.584 & 0.741 \\
LGSC & $\mathbf{0 . 1 2 9}$ & 0.015 & $\mathbf{0 . 1 5 0}$ & & 1.611 & 1.200 \\
CSRS & 0.030 & 0.029 & 0.039 & $\mathbf{0 . 0 4 8}$ & & 0.923 \\
SFRS & $\mathbf{0 . 0 6 6}$ & $\mathbf{0 . 1 2 9}$ & $\mathbf{0 . 1 0 6}$ & $\mathbf{0 . 1 6 9}$ & 0.043 & \\
\hline
\end{tabular}

$F_{\text {ST }}$ values in bold were significant at $P<0.001$.

generation in $V$. reitzii populations varied from 0.145 to 2.671 (Table 3), with approximately half of the comparisons between populations pairs exceeding 1, which is equivalent to $>1$ migrant per generation. The minimum migration required for maintaining species cohesion has traditionally been regarded to be one migrant per generation (Morjan and Rieseberg, 2004). Confidence intervals for the effective number of migrants $\left(N_{\mathrm{e}} \mathrm{m}\right)$ are presented in Table S2.

\section{Discussion}

\section{Genetic diversity within populations}

We investigated the genetic diversity and population structure of $V$. reitzii, a species endemic to the MOF, by using nuclear microsatellite markers. Mountains, islands and even forest fragments are often rich in endemism, but these habitats are commonly at risk of depauperization, causing a reduction of genetic diversity of its populations (Kruckeberg and Rabinowitz, 1985). According to Furtado and Menini-Neto (2015), the particular features of mountainous regions confer them high indices of species richness and cause them to harbor important forest remnants in the form of vegetation islands. However, these ecosystems can be very sensitive to anthropogenic disturbances (Zhao and Gong, 2015). Here, despite the fact that $V$. reitzii is endemic to the southern region of Brazil and restricted to the MOF, a highly particular mountain environment with high anthropogenic influence, we did not find low levels of genetic diversity in the populations sampled across its geographical range. Our results revealed that the levels of genetic diversity in this species are relatively high (Table 2). Although a direct comparison of genetic diversity levels between species is complicated by the use of different methods, the levels of diversity found for $V$. reitzii can be considered high when compared to other studies on Bromeliaceae that are based on many of the same SSR loci (Table S1) used in the present study (Palma-Silva et al., 2009; Zanella et al., 2011, 2016; Cascante-Marín et al., 2014; Lavor et al., 2014; Goetze et al., 2015, 2016). The genetic diversity encountered within $V$. reitzii populations suggests that these populations have not yet been impacted by habitat fragmentation, and genetic drift has not yet decreased within-population genetic diversity. Therefore, although the MOF has suffered a long history of natural fragmentation (Fonseca et al., 2009), V. reitzii populations have been able to maintain a moderate to high genetic diversity.

Many recent studies have demonstrated that the rarity or endemicity of a species is not necessarily synonymous with low genetic diversity. Instead, genetic diversity can be influenced by species life-history traits, such as a recent origin from widespread congeners, hybridization, maintenance of genetic diversity within refugial populations, as well as ecological traits, habit and mating system (TorresDíaz et al., 2007; Ægisdóttir et al., 2009; Hardcastle and Gentry, 2009; Eliades et al., 2011; Goetze et al., 2015; Turchetto et al., 2016). The relatively high genetic diversity found in populations of $V$. reitzii $\left(R_{\mathrm{S}}=3.589-5.531\right.$ and $H_{\mathrm{O}}$ $=0.360-0.499)$ may be related to its life history, such as clonality and an outcrossing reproductive system. Outcrossing plants generally have high within-population genetic diversity (Hamrick and Godt, 1996), and clonal propagation can increase the longevity of genets (Orive, 1993; Goetze et al., 2015). The combination of genet longevity and outcrossing may maintain genetic diversity in fragmented populations (Xiao et al., 2015). The reproductive biology of $V$. reitzii and its breeding system have not yet been studied. However, we assume that it has a mixed mat-

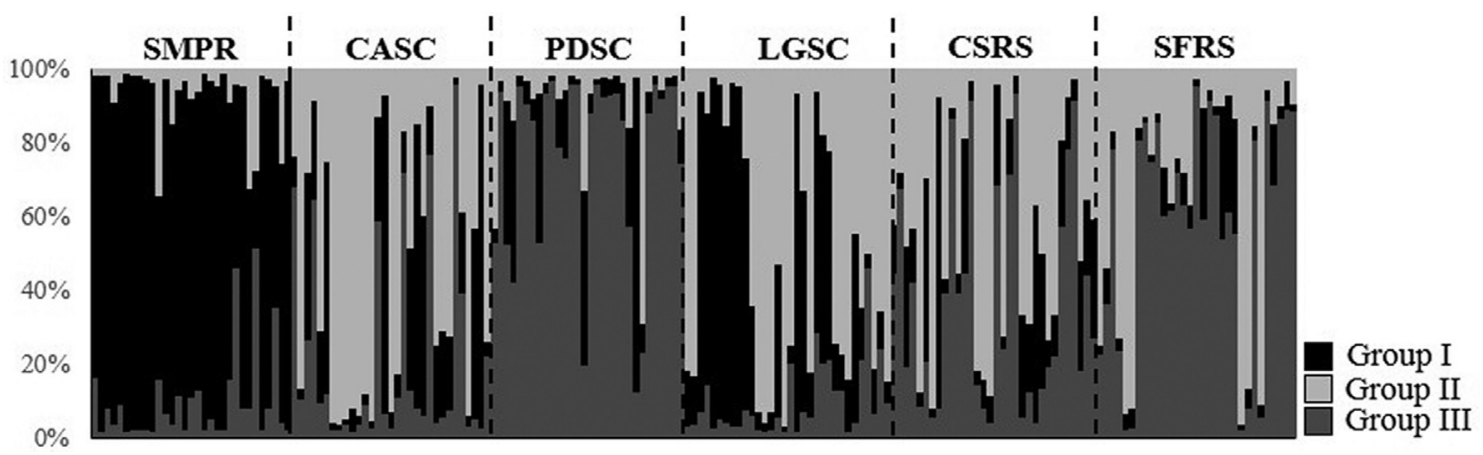

Figure 2 - Population structure in Vriesea reitzii using Bayesian assignment analysis for a $K=3$ population model based of seven nuclear microsatellite loci. See Table 1 for population identification. 
ing system, like most Vriesea species studied to date (Zanella et al., 2012; Lavor et al., 2014). We also presume that, like its sister species $V$. phillipocoburgii and $V$. altodaserrae, it is pollinated by hummingbirds (Machado and Semir, 2006). Moreover, although the species' clonality has not yet been formally studied, we observed evident clonal reproduction on our field trips.

Another factor potentially explaining the occurrence of high levels of genetic diversity in this mountain species is that its population may have been founded by multiple genetically diverse individuals. This initial diversity may have been maintained in the stable mountainous conditions throughout the Quaternary glacial/interglacial cycles (Behling and Pillar, 2007), thanks to a combination of relatively large population sizes and recurrent interpopulation gene flow, as reported in the terrestrial orchid Oreorchis patens from the Korean mountains (Chung et al., 2012). Since $V$. reitzii is highly associated with the Araucaria forest, the expansion of the Araucaria forest over the Southern Brazilian Highlands from the late Quaternary until 1500-1000 years ago (Behling et al., 2004) might have increased population connectivity, thereby representing one possible reason for the great allelic richness encountered here.

Despite their high levels of genetic diversity, almost all populations significantly departed from HWE. Heterozygote deficiency may result from many factors, such as genetic drift and inbreeding. Alternatively, it can occur due to the presence of null alleles (Lavor et al., 2014; Turchetto et al., 2016). We found null alleles at all loci in different populations; however, to relate the excess of homozygotes to biparental inbreeding or drift, we would need to have access to demographic data of the populations. Assuming that $V$. reitzii has a mixed mating system, as many other species of the genus Vriesea (Paggi et al., 2007; Lavor et al., 2014), mating among relatives may potentially occur within populations. In the only existing record on ecological and demographic aspects of V. reitzii, Favretto and Geuster (2012) report that the species is rare in environments with very dense vegetation, but abundant in places with more dispersed trees, and that it is one of the few species that colonizes Araucaria angustifolia in the region of Joaçaba, Santa Catarina, Brazil. In the same study, the authors describe the occurrence of 360 individuals across $2000 \mathrm{~m}^{2}$, demonstrating that, wherever they occur, $V$. reitzii populations are abundant; this is consistent with our own observations. High population densities may influence the amount of pollen available for outcrossing in mixed mating species and may have an affect on the rate of selfing and inbreeding (Duminil et al., 2016). In the congener $V$. minarum, an excess of homozygotes has been attributed to selfing or biparental inbreeding, since that species has a mixed reproductive strategy (Lavor et al., 2014). Considering that similar results had been found in many species studied so far,
Lavor and colleagues also speculated that their findings might reflect a general pattern characteristic of the family.

It would be interesting to compare the patterns of diversity found in the present study with those of other species endemic to the MOF, however, our exhaustive search turned up very few studies with a genetic focus, and most of these were on Araucaria angustifolia (Auler et al., 2002; Bittencourt and Sebbenn, 2007; Medina-Macedo et. al., 2015). Dicksonia sellowiana is a species of the MOF whose populations were severely reduced due to direct exploitation. Montagna et al. (2012) compared the genetic diversity of populations from conservation units to that of populations outside conservation units and found a significant difference in $\mathrm{Ho}$ between these two groups. Martins et al. (2015) studied populations of Ocotea spp. in protected and unprotected areas of the MOF and found high $H \mathrm{o}$ indexes and a small heterozygous deficit. However, none of the studies focused on understanding the dynamics and genetic structure of populations from the mosaic landscape characterizing the MOF, highlighting the importance of the present work in contributing to an improved understanding of the dynamics of MOF species.

\section{Genetic differentiation among populations}

Mountainous and fragmented environments are characterized by landscape heterogeneity, with the mountain ridges or mosaic formations expected to represent major barriers to gene flow among populations (Zhan et al., 2009; Frei et al., 2010). However, against this expectation, we observed an average $F_{\mathrm{ST}}$ of 0.123 and an average $R_{\mathrm{ST}}$ of 0.0964, indicating only a moderate differentiation among V. reitzii populations (Balloux and Lugon-Moulin, 2002). The similarity between $F_{\mathrm{ST}}$ and $R_{\mathrm{ST}}$ estimates suggests that drift and mutation are jointly responsible for the observed level of population differentiation (Balloux and LugonMoulin, 2002). The results of studies on differentiation among populations in this kind of landscape can vary widely from species to species (Byars et al., 2009). In the Bromeliaceae, various studies have estimated the variation among populations from outcrops and inselbergs. Domingues et al. (2011), Barbará et al. (2009) and BoisselierDubayle et al. (2010) found a high level of population structure in several bromeliad species. Other authors have reported moderate indices of genetic structure, similar to our results for $V$. reitzii (Ribeiro et al., 2013; Lavor et al., 2014).

No correlation between genetic and geographic distances was detected by the Mantel test $\left(r^{2}=0.0001, P=\right.$ 0.364 ), indicating an absence of isolation-by-distance among $V$. reitzii populations. Furthermore, Bayesian analysis revealed that $V$. reitzii comprises three genetic groups (Figure 2 and Figure S1). These did not correlate to the geography of sampling localities, and we could find individuals with a predominance of the three genetic components in almost all populations (Figure 2). An evaluation of the re- 
gion's topography did not reveal any obvious features that could have led to the formation of the groups found. The next step will be to use plastidial markers in a phylogeographic approach to assess the historical structure of the populations and indicate possible vicariance events underlying the observed pattern. The weak genetic structure between groups, paired with the high number of migrants per generation found in at least half of the population pairs (Table 3), points towards reasonable levels of gene flow among localities. In order to explain this moderate structure and the estimated effective number of migrants, it is possible to relate them to ancient and contemporary factors.

Concerning contemporary gene flow, to date, there are no studies on the pollinator and seed dispersal mechanisms of $V$. reitzii. However, if the species is pollinated by hummingbirds, an effective contemporary gene flow among the populations sampled may occur. Hummingbird behavior varies between species, but some species can migrate up to $2000 \mathrm{~km}$, enough to cover the inter-population distances of $V$. reitzii, which range from $38 \mathrm{~km}$ to $360 \mathrm{~km}$ (Berthold et al., 2013). Furthermore, V. reitzii has plumose seeds (LES personal observation; Leme and Costa, 1991), which is characteristic of the subfamily Tillandsioideae (Benzing, 1990) and can facilitate seed dispersal by wind over long distances. In a study of the bromeliad $V$. gigantea, an epiphyte inhabiting the understory of the Atlantic Forest, Paggi et al. (2010) showed that seed dispersal occurs over short distances, although the species' seeds are plumose and wind-dispersed, as they probably are in $V$. reitzii. On the other hand, Lavor et al. (2014) reported that seed dispersal in $V$. minarum is more effective and not directly comparable to the results of Paggi et al. (2010). Vriesea minarum is restricted to rocky systems in open environments, where the high incidence of winds can enhance seed dispersal. In addition, the usually low stature of the rupicolous vegetation poses fewer obstacles to dispersal than a forested area.

With regard to ancient patterns of gene flow, the current design of genetic structure may have been modeled by past events, such as the expansion of the Araucaria forest during the Holocene (Behling and Pillar, 2007) that may have contributed to decrease the distance between populations and increase the gene flow between them. Chung et al. (2012), studying orchids of the genus Oreorchis, suggested a scenario of high levels of historical gene flow among neighboring populations along the main mountainous ranges in the Korean Peninsula. In a study on the altitudinal gradients of Silene ciliate, García-Fernández et al. (2012) proposed that the high genetic similarity among populations from different mountains may be due to historical population movements related to glacial contractions and expansions throughout the Quaternary period. Many montane-adapted species exist as isolated populations under todays relatively warm climate; during cooler glacial cycles, these species would have experienced range expan- sions, increasing population connectivity and gene flow (Devitt et al., 2013). Moreover, both the results of the heterozygosity excess test (Bottleneck program) and the $M$-ratio found here indicate that $V$. reitzii populations did not suffer a bottleneck or reduction of genetic diversity (Table 2), emphasizing that factors involved in the evolutionary history of the MOF might have significantly contributed to genetically homogenize the populations. In this context, it would be interesting to collect data from additional species from the MOF in order to further investigate this hypothesis.

Therefore, the current genetic pattern of $V$. reitzii populations may have been shaped by a range of factors, including the mosaic landscape of alternating grasslands and forests. The Araucaria Plateau, where we sampled $V$. reitzii populations, is formed by lightly to markedly undulating terrain at altitudes between 600 and $<1400 \mathrm{~m}$. The MOF's current mosaic landscape has been shaped by the phases of forest expansion and retraction resulting from climatic changes during the Holocene (Calegari et al., 2017). Coupled with the intense fragmentation of this environment in the twentieth century (Fonseca et al., 2009), the patchwork pattern of this landscape may have influenced the current patterns of diversity and population structure found in $V$. reitzii. In summary, the moderate structure encountered in $V$. reitzii may be due to ancient gene flow, facilitated dispersal mediated by the mosaic landscape of the MOF, or a combination of these two factors.

\section{Implications for Conservation}

Vriesea reitzii populations showed high genetic diversity and moderate genetic structure, indicating no imminent threat to this bromeliad. However, as an epiphyte, this species is highly associated with the MOF, and the conservation of this landscape is therefore paramount for the species' maintenance. Only $12.6 \%$ of the Araucaria Forest's original cover remains, and those remnants are mostly distributed in small fragments amid various anthropogenic habitats, such as pasture, agriculture and exotic tree monocultures of Pinus and Eucalyptus (Ribeiro et al., 2009; Emer and Fonseca, 2011). The Araucaria Forest should therefore be considered as critically threatened.

Despite the moderate levels of genetic differentiation between $V$. reitzii populations, almost all have private alleles (Table 2), emphasizing the importance of the conservation of this genetic diversity. The CASC and LGSC populations have four and six private alleles respectively; they therefore deserve special attention in any conservation measures.

If the mixed mating system in $V$. reitzii is confirmed, with at least partial dependence on pollinators, strategies for the maintenance of gene flow among forest fragments should be put in place. Studies on reproductive biology and pollination will be essential to paint a complete picture of the biology of this species. 


\section{Acknowledgments}

The authors thank the staff of C. Migliavacca, Parque Nacional Aparados da Serra and Parque Natural Municipal João José Theodoro da Costa Neto for helping to collect samples. We also thank IBAMA (Instituto Brasileiro do Meio Ambiente e dos Recursos Naturais Renováveis) for processing collection permits as well MV Büttow and F Capra for assistance during the field work and C PalmaSilva for help in the analysis. Research was supported by CNPq (Conselho Nacional de Desenvolvimento Científico e Tecnológico) and PPGBM (Programa de Pós Graduação em Genética e Biologia Molecular — UFRGS).

\section{References}

Ægisdóttir HH, Kuss P and Stöcklin J (2009) Isolated populations of a rare alpine plant show high genetic diversity and considerable population differentiation. Ann Bot 104:1313-1322.

Alves GM, Filho AR, Puchalski A, Reis MS, Nodari RO and Guerra MP (2004) Allozymic markers and genetic characterization of a natural population of Vriesea friburgensis var. paludosa, a bromeliad from the Atlantic Forest. Plant Genet Resour 2:23-28.

Alves GM, Dal Vesco LL and Guerra MP (2006) Micropropagation of the Brazilian endemic bromeliad Vriesea reitzii trough nodule clusters culture. Sci Hort 110:204-207.

Auler NMF, dos Reis MS, Guerra MP and Nodari RO (2002) The genetics and conservation of Araucaria angustifolia: I. Genetic structure and diversity of natural populations by means of non-adaptive variation in the state of Santa Catarina, Brazil. Genet Mol Biol 25:329-338.

Balloux F and Lugon-Moulin N (2002) The estimation of population differentiation with microsatellite markers. Mol Ecol 11:155-165.

Barbará T, Martinelli G, Fay MF, Mayo SJ and Lexer C (2007) Population differentiation and species cohesion in two closely related plants adapted to neotropical high-altitude 'inselbergs', Alcantarea imperialis and Alcantarea geniculata (Bromeliaceae). Mol Ecol 16:1981-1992.

Barbará T, Martinelli G, Palma-Silva C, Fay MF, Mayo S and Lexer C (2009) Genetic relationships and varitation in reproductive strategies in four closely related bromeliads adapted to neotropical 'inselbergs': Alcantarea glaziouana, A. regina, A. geniculata and A. imperialis (Bromeliaceae). Ann Bot 103:65-77.

Barfuss MHJ, Till W, Leme EMC, Pinzón JP, Manzanares JM, Halbritter H, Samuel R and Brown GK (2016) Taxonomic revision of Bromeliaceae subfam. Tillandsioideae based on a multi-locus DNA sequence phylogeny and morphology. Phytotaxa 279:1-97.

Beerli P and Felsenstein J (1999) Maximum-likelihood estimation of migration rates and effective population numbers in two populations using a coalescent approach. Genetics 152:763-773.

Behling H and Pillar VD (2007) Late Quaternary vegetation, biodiversity and fire dynamics on the southern Brazilian highland and their implication for conservation and management of modern Araucaria forest and grassland ecosystems. Phil Trans R Soc 362:243-251.
Behling H, Pillar VD, Orlóci L and Bauermann SG (2004) Late Quaternary Araucaria forest, grassland (Campos), fire and climate dynamics, studied by high resolution pollen, charcoal and multivariate analysis of the Cambará do Sul core in southern Brazil. Palaeogeogr Palaeoclimatol Palaeoecol 203:277-297.

Behling H, Pillar VD and Bauermann SG (2005) Late Quaternary grassland (Campos), gallery forest, fire and climate dynamics, studied by pollen, charcoal and multivariate analysis of the São Francisco de Assis core in western Rio Grande do Sul (southern Brazil). Rev Paleobot Palinol 133:235-248.

Benzing DH (1990) Vascular Epiphytes: General Biology and Related Biota. Cambridge University Press, Cambridge, 354 p.

Benzing D (2000) Bromeliaceae: Profile of an Adaptive Radiation. Cambridge University Press, Cambridge, 690 p.

Berthold P, Gwinner E and Sonnenschein E (2013) Avian Migration. Springer Science \& Business Media, Heidelberg, 610 p.

Bittencourt JVM and Sebbenn AM (2007) Patterns of pollen and seed dispersal in a small fragmented population of the wind-pollinated tree Araucaria angustifolia in southern Brazil. Heredity 99:580-591.

Boelter CR, Zartman CE and Fonseca CR (2011) Exotic tree monocultures play a limited role in the conservation of Atlantic Forest epiphytes. Biodivers Conserv 20:1255-1272.

Boisselier-Dubayle MC, Leblois R, Samadi S, Lambourdière J and Sarthou C (2010) Genetic structure of the xerophilous bromeliad Pitcairnia geyskesii on inselbergs in French Guiana - a test of the forest refuge hypothesis. Ecography 33:175-184.

Boneh L, Kuperus P and Van Tienderen PH (2003) Microsatellites in the bromeliads Tillandsia fasciculata and Guzmania monostachya. Mol Ecol Notes 3:302-303.

Brown GK and Gilmartin AJ (1989) Chromosome-numbers in Bromeliaceae. Am J Bot 76:657-665.

Byars SG, Parsons Y and Hoffmann AA (2009) Effect of altitude on the genetic structure of an Alpine grass, Poa hiemata. Ann Bot 103:885-899.

Calegari MR, Paisani SDL, Cecchet FA, Ewald PLL, Osterrieth ML, Paisani JC and Pontelli ME (2017) Phytolith signature on the Araucarias Plateau - Vegetation change evidence in Late Quaternary (South Brasil). Quatern Int 434:117-128.

Cascante-Marín A, Oostermeijer G, Wolf J and Fuchs EJ (2014) Genetic diversity and spatial genetic structure of an epiphytic bromeliad in Costa Rican montane secondary forest patches. Biotropica 46:425-432.

Chung MY, López-Pujol J, Maki M, Kim KJ, Chung JM, Sun BY and Chung MG (2012) Genetic diversity in the common terrestrial orchid Oreorchis patens and its rare congener Oreorchis coreana: Inference of species evolutionary history and implications for conservation. J Hered. 103:692702.

Costa AF, Gomes-da-Silva J and Wanderley MGL (2014) Vriesea (Bromeliaceae, Tillandsioideae): taxonomic history, and morphology of the Brazilian lineage. J Torr Bot Soc 141:338-352.

Danner MA, Ribeiro JZ, Zanette F, Bittencourt JVM and Sebbenn AM (2013) Impact of monoecy in the genetic structure of a predominately dioecious conifer species, Araucaria angustifolia (Bert.) O. Kuntze. Plant Syst Evol 299:949-958.

Devitt TJ, Devitt SEC, Hollingsworth BD, McGuire JA and Moritz C (2013) Montane refugia predict population genetic 
structure in the Large-blotched Ensatina salamander. Mol Ecol 22:1650-1665.

Dieringer D and Schlotterer C (2003) Microsatellite Analyser (MSA): A platform independent analysis tool for large microsatellite data sets. Mol Ecol Notes 3:167-169.

Domingues R, Machado MA, Forzza RC, Melo TD, WohlresVianna S and Viccini LF (2011) Genetic variability of an endangered Bromeliaceae species (Pitcairnia albiflos) from the Brazilian Atlantic rainforest. Genet Mol Res 10:24822491.

Doyle JJ and Doyle JL (1990) Isolation of plant DNA from fresh tissue. Focus 12:13-15.

Duminil J, Daïnou K, Kaviriri DK, Gillet P, Loo J, Doucet JL and Hardy OJ (2016) Relationships between population density, fine-scale genetic structure, mating system and pollen dispersal in a timber tree from African rainforests. Heredity 116:295-303.

Earl DA and von Holdt BM (2012) Structure Harvester: A website and program for visualizing Structure output and implementing the Evanno method. Conserv. Genet Resour 4:359361.

Eliades NGH, Gailing O, Leinemann L and Finkeldey BFR (2011) High genetic diversity and significant population structure in Cedrus brevifolia Henry, a narrow endemic Mediterranean tree from Cyprus. Plant Syst Evol 294:185198.

Emer C and Fonseca CR (2011) Araucaria Forest conservation: Mechanisms providing resistance to invasion by exotic timber trees. Biol Invasions 13:189-202.

Evanno G, Regnaut S and Goudet J (2005) Detecting the number of clusters of individuals using the software STRUCTURE: A simulation study. Mol Ecol 14:2611-2620.

Excoffier L, Smouse PE and Quattro JM (1992) Analysis of molecular variance inferred from metric distances among DNA haplotypes: Application to human mitochondrial DNA restriction data. Genetics 131:479-491.

Excoffier L and Lischer HEL (2010) Arlequin suite Version 3.5: A new series of programs to perform population genetics analyses under Linux and Windows. Mol Ecol Resour 10:564-567.

Favretto MA and Geuster CJ (2012) Parque Natural Municipal Rio do Peixe, Joaçaba, Santa Catarina, Vol II, Plantas Epífitas. Edited by the author, Joaçaba, 85 p.

Fonseca CR, Ganade G, Baldissera R, Becker CG, Boelter R, Brescovit AD, Campos LM, Fleck T, Fonseca VS, Hartz SM, et al. (2009) Towards an ecologically-sustainable forestry in the Atlantic Forest. Biol Conserv 142:1209-1219.

Frei ES, Bodin J and Walther GR (2010) Plant species' range shifts in mountainous areas: all uphill from here? Bot Helvet 120:117-128.

Frei ES, Scheepens JF and Stöcklin J (2012) High genetic differentiation in populations of the rare alpine plant species Campanula thyrsoides on a small mountain. Alp Bot 122:23-34.

Furtado SG and Menini-Neto L (2015) Diversity of vascular epiphytes in two high altitude biotopes of the Brazilian Atlantic Forest. Braz J Bot 38:295-310.

García-Fernández A, Iriondo JM, Vallès J, Orellana J and Escudero A (2012) Ploidy level and genome size of locally adapted populations of Silene ciliata across an altitudinal gradient. Plant Syst Evol 298:139-146.

Givnish TJ, Barfuss MHJ, Van Ee B, Riina R, Schulte K, Horres R, Gonsiska PA, Jabaily RS, Crayn DM, Brown GK, et al.
(2014) Adaptive radiation, correlated and contingent evolution, and net species diversification in Bromeliaceae. Mol Phylogenet Evol 71:55-78.

Goetze M, Büttow MV, Zanella CM, Paggi GM, Bruxel M, Pinheiro FP, Sampaio JAT, Palma-Silva C, Cidade, FW and Bered F (2015) Genetic variation in Aechmea winkleri, a bromeliad from an inland Atlantic rainforest fragment in southern Brazil. Biochem Syst Ecol 58:204-210.

Goetze M, Palma-Silva C, Zanella CM and Bered F (2016) Eastto-west genetic structure in populations of Aechmea calyculata (Bromeliaceae) from the southern Atlantic rainforest of Brazil. Bot J Linn Soc 181:477-490.

Goudet J (1995) FSTAT (Version 1.2): A computer program to calculate F- statistics. J Hered 86:485-486.

Hamrick JL and Godt MJW (1996) Conservation genetics of endemic plant species. In: Avise JC and Hamrick JL (eds) Conservation Genetics: Case Histories From Nature. Chapman and Hall, New York, pp 281-304.

Hardcastle EL and Gentry JL (2009) Conservation genetics of Delphinium newtonianum Dw. Moore (Moore's Delphinium) [Ranunculaceae], a rare endemic of the interior highlands. Castanea 74:41-52.

Hedrick P (2005) A standardized genetic differentiation measure. Ecology 59:1633-1638.

Kruckeberg AR and Rabinowitz D (1985) Biological aspects of endemism in higher plants. Annu Rev Ecol Syst 16:447-479.

Lavor P, van den Berg C, Jacobi CM, Carmo FF and Versieux LM (2014) Population genetics of the endemic and endangered Vriesea minarum (Bromeliaceae) in the Iron Quadrangle, Espinhaço Range, Brazil. Am J Bot 101:1167-1175.

Ledru MP, Montade V, Blanchard G and Hély C (2016) Longterm spatial changes in the distribution of the Brazilian Atlantic Forest. Biotropica 48:159-169.

Leme EMV and Costa A (1991) A new species from Southern Brazil: A tribute to Father Raulino Reitz. J Brom Soc 41:195-198.

Machado CG and Semir J (2006) Fenologia da floração e biologia floral de bromeliáceas ornitófilas de uma área da Mata Atlântica do Sudeste brasileiro. Rev Bras Bot 291:163-174.

Martinelli G, Vieira CM, Gonzalez M, Leitman P, Piratininga A, Costa AF and Forzza RC (2008) Bromeliaceae da Mata Atlântica Brasileira: Lista de espécies, distribuição e conservação. Rodriguésia 59:209-258.

Martins EM, Lamont RW, Martinelli G, Lira-Medeiros CF, Quinet A and Shapcott A (2015) Genetic diversity and population genetic structure in three threatened Ocotea species (Lauraceae) from Brazil's Atlantic Rainforest and implications for their conservation. Conserv Genet 16:1-14.

Maurice T, Matthies D, Muller S and Colling G (2016) Genetic structure of colline and montane populations of an endangered plant species. AoB Plants 8:plw057.

Medina-Macedo L, Sebbenn AM, Lacerda AEB, Ribeiro JZ, Soccol CR and Bittencourt JVM (2015) High levels of genetic diversity through pollen flow of the coniferous Araucaria angustifolia: a landscape level study in Southern Brazil. Tree Genet Genomes 11:814.

Montagna T, Ferreira DK, Steiner F, Fernandes CD, Bittencourt R, Silva JZ, Mantovani A and dos Reis MS (2012) A Importância das unidades de conservação na manutenção da diversidade genética de xaxim (Dicksonia sellowiana) no Estado de Santa Catarina. ICMBio 2:26-32. 
Morjan CL and Rieseberg LH (2004) How species evolve collectively: Implications of gene flow and selection for the spread of advantageous alleles. Mol Ecol 13:1341-1356.

Oliveira Filho AT and Fontes MAL (2000) Patterns of floristic differentiation among Atlantic forests in southeastern Brazil and the influence of climate. Biotropica 32:793-810.

Orive ME (1993) Effective population size in organisms with complex life-histories. Theor Pop Biol 44:316-340.

Paggi GM, Palma-Silva C, Silveira LCT, Kaltchuk-Santos E, Bodanese-Zanettini MH and Bered F (2007) Fertility of Vriesea gigantea Gaud. (Bromeliaceae) in Southern Brazil. Am J Bot 94:683-689.

Paggi GM, Palma-Silva C, Bered F, Cidade FW, Sousa ACB, Souza AP, Wendt T and Lexer C (2008) Isolation and characterization of microsatellite loci in Pitcarirnia abiflos (Bromeliaceae), and endemic bromeliad of Atlantic Rainforest, an cross-amplification in other species. Mol Ecol Resour 8:980-982.

Paggi GM, Sampaio JAT, Bruxel M, Zanella CM, Goetze M, Büttow MV, Palma-Silva C and Bered F (2010) Seed dispersal and population structure in Vriesea gigantea, a bromeliad from the Brazilian Atlantic Rainforest. Bot J Linn Soc 164:317-325.

Palma-Silva C, Cavallari MM, Barbará T, Lexer C, Gimenes MA, Bered F and Bodanese-Zanettini MH (2007) A set of polymorphic microsatellite loci for Vriesea gigantea and Alcantarea imperialis (Bromeliaceae) and crossamplification in other bromeliad species. Mol Ecol Notes 7:654-657.

Palma-Silva C, Lexer C, Paggi GM, Barbará T, Bered F and Bodanese-Zanettini MH (2009) Range-wide patterns of nuclear and chloroplast DNA diversity in Vriesea gigantea (Bromeliaceae), a Neotropical forest species. Heredity 103:503-512.

Piry S, Luikart G and Cornuet JM (1999) Bottleneck: A computer program for detecting recent reductions in the effective population size using allele frequency data. J Hered 90:502-503.

Pritchard JK, Stephens M and Donnelly P (2000) Inference of population structure using multilocus genotype data. Genetics 155:945-959.

Raymond M and Rousset F (1995) GENEPOP (version 1.2): Population genetics software for exact tests and ecumenicism. J Heredity 86:248-249.

Rech-Filho A, Dal Vesco LL, Nodari RO, Lischka RW, Müller CV and Guerra MP (2005) Tissue culture for the conservation and mass propagation of Vriesea reitzii Leme and Costa, a bromeliad threatened of extinction from the Brazilian Atlantic Forest. Biodiv Conserv 14:1799-1808.

Ribeiro MC, Metzger JP, Martensen AC, Ponzoni FJ and Hirota MM (2009) The Brazilian Atlantic Forest: How much is left, and how is the remaining forest distributed? Implications for conservation. Biol Conserv 142:1141-1153.

Ribeiro PCC, Pinheiro LC, Domingues R, Forzza RC, Machado MA and Viccini LF (2013) Genetic diversity of Vriesea cacuminis (Bromeliaceae): an endangered and endemic Brazilian species. Genet Mol Res 12:1934-1943.

Sgorbati S, Labra M, Grugni E, Barcaccia G, Galasso G, Boni U, Mucciarelli M, Citterio S, Benavides Iramátegui A, Venero Gonzalez L, et al. (2004) A survey of genetic diversity and reproductive biology of Puya raimondii (Bromeliaceae), the endangered queen of the Andes. Plant Biol 6:222-230.

Slatkin M (1995) A measure of population subdivision based on microsatellite allele frequencies. Genetics 139:457-462.
Smith LB and Till W (1999) Bromeliaceae. In: Kubitzki K (ed) The Families and Genera of Vascular Plants. Springer, Berlin, pp 74-99.

Sokal RR and Rohlf FJ (1995) Biometry. 3rd edition. W.H. Freeman, New York, 887 p.

Torres-Díaz C, Ruiz E, González F, Fuentes G and Cavieres LA (2007) Genetic diversity in Nothofagus alessandrii (Fagaceae), an endangered endemic tree species of the coastal Maulino Forest of Central Chile. Ann Bot 100:75-82.

Turchetto C, Segatto AL, Mäder G, Rodrigues DM, Bonatto SL and Freitas LB (2016) High levels of genetic diversity and population structure in an endemic and rare species: implications for conservation. AoB Plants 8:plw002.

van Oosterhout C, Hutchinson WF, Wills DPM and Shipley PF (2004) MICRO-CHECKER: For identifying and correcting genotyping errors in microsatellite data. Mol Ecol Notes 4:535-538.

Weir BS and Cockerham CC (1984) Estimating F-statistics for the analysis of population structure. Evolution 38:1358-1370.

Wright S (1965) The interpretation of population structure by F-statistics with special regards to system of mating. Evolution 19:395-420.

Xiao YE, Jiang K, Tong X, Hu YH and Chen XY (2015) Population genetic structure of Iris ensata on sky-islands and its implications for assisted migration. Conserv Genet 16:1055-1067.

Zanella CM, Bruxel M, Paggi GM, Goetze M, Büttow MV, Cidade FW and Bered F (2011) Genetic structure and phenotypic variation in wild populations of the medicinal tetraploid species Bromelia antiacantha (Bromeliaceae). Am J Bot 98:1511-1519.

Zanella CM, Janke A, Palma-Silva C, Kaltchuk-Santos E, Pinheiro FG, Paggi GM, Soares LES, Goetze M, Büttow MV and Bered F (2012) Genetics, evolution and conservation of Bromeliaceae. Genet Mol Biol 4:1020-1026.

Zanella CM, Palma-Silva C, Goetze M and Bered F (2016) Hybridization between two sister species of Bromeliaceae: Vriesea carinata and $V$. incurvata. Bot J Linn Soc 181:491-504.

Zhan A, Li C and Fu J (2009) Big mountains but small barriers: Population genetic structure of the Chinese wood frog (Rana chensinensis) in the Tsinling and Daba Mountain region of northern China. BMC Genetics 10:17.

Zhao YJ and Gong X (2015) Diversity and conservation of plant species in dry valleys, southwest China. Biodivers Conserv 24:2611-2623.

\section{Supplementary material}

The following online material is available for this article:

Figure S1 - Magnitude of $\Delta K$ from structure analysis of $K$. Table S1 - Genetic characterization for seven microsatellite loci.

Table S2 - Confidence intervals of number of effective migrants $\left(N_{\mathrm{e}} \mathrm{m}\right)$ estimated for Vriesea reitzii populations based on seven microsatellite loci.

Associate Editor: Loreta B. Freitas

License information: This is an open-access article distributed under the terms of the Creative Commons Attribution License (type CC-BY), which permits unrestricted use, distribution and reproduction in any medium, provided the original article is properly cited. 